\title{
The effect of macro variables on the Jakarta Islamic Index
}

\author{
Thoha Yahya \\ Faculty of Business and Economics, Universitas Islam Indonesia, Yogyakarta, \\ Indonesia \\ Corresponding author: thoha.yahya01@gmail.com
}

\author{
Article History \\ Received, April 23, 2020 \\ Revised 1, 10 May 2020 \\ Revised 2, 23 May 2020 \\ Accepted, 26 May 2020
}

\begin{abstract}
Purpose: In this study, efforts have been made to explore the relationship between macroeconomic variables and the Jakarta Islamic Index during the period 2015.1-2019.8.
\end{abstract}

Methodology: the formulated model is a model to show the relationship. Long-term and short-term analysis using the classic assumption test and unit root test, co-integration test, and Granger causality test in the context of the ECM framework. For this purpose, macroeconomic variables are used as a measure of influence on the Jakarta Islamic Index

Findings: The results showed. Based on the analysis that has been done through cointegration and ECM tests, there is a long-term relationship between inflation variables, BI interest rates, foreign exchange rates, and the money supply with JII in 2015.1-2019.8. There is a short-term relationship between inflation variables, BI interest rates, foreign exchange rates, and the money supply with JII in 2015.1-2019.8.

Originality/contributions: This is the first study using JII in Indonesia which was registered at the Islamic University of Indonesia in 2015.1-2019.8

Keywords: Macroeconomic variables, ECM, sharia shares, JII

Cite this:

Yahya, T. (2020). The influence of macro variables on the Jakarta Islamic Index (JII). Asian Journal of Islamic Management, 2 (1), 36-45. DOI: 10.1108/AJIM.vol2.iss1.art4

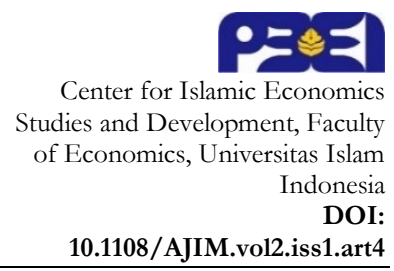

\section{Introduction}

In the current global economy the capital market has a very important role as a financial development. As a developing country, Indonesia has a capital market that participates in developing the country's economy by raising funds, investment sites, selling shares, and issuing bonds. The capital market itself has an important role in financing companies. Capital market according to Law No. 8 of 1995 article 1 paragraph (12) is the activities of companies, institutions, and public professions that have a relationship with the public offering and Securities trading that they issue.

Hence, it can be said that the capital market is a meeting place for sellers and buyers in making transactions to obtain capital (Soemitra, 2009). Although the Islamic capital market was only inaugurated in 2003, the instrument has been in existence since 1997 and has developed with the Jakarta Islamic Index (JII) which aims to guide investors to invest their capital in a sharia manner.

The Jakarta Islamic Index (JII) and the Indonesian Sharia Stock Index are among the largest capital markets in Indonesia, where investments have risen throughout the year marked by the Composite Stock Price Index (CSPI) which is getting better. JII itself is an increase in capitalization can be seen through data on the Indonesia Stock Exchange below. This condition 
occurs because of the increasing knowledge of the public about the capital market and the more easily the public in finding information. So that people understand that they will invest. In Indonesia, where the majority of the population is predominantly Muslim, they are very interested in sharia-based investments. There are so many forms of sharia investment in the capital market, one of which is sharia stock investment.

Table 1. Development of Jakarta Islamic Index (JII)

\begin{tabular}{cccccc}
\hline Tahun & JII & INF & BIR & ER & JUB \\
\hline 2015 & $1.843 .183,20$ & 6,38 & 7,52 & $13.457,58$ & $4.357 .519,48$ \\
2016 & $2.001 .639,67$ & 3,53 & 5,58 & $13.329,83$ & $4.698 .476,66$ \\
2017 & $2.162 .839,91$ & 3,81 & 4,56 & $13.398,17$ & $5.163 .295,28$ \\
2018 & $2.126 .460,65$ & 3,20 & 5,10 & $14.267,33$ & $5.518 .336,63$ \\
2019 & $2.225 .135,17$ & 3,01 & 5,91 & $14.172,75$ & $5.806 .806,75$ \\
\hline
\end{tabular}

Table 1 shows the ups and downs of JII followed by macroeconomic variable fluctuations, including inflation, exchange rates, interest rates and the money supply. From Table 1 , it also shows the changes in inflation which respond to the changes in JII. Different changes in inflation will result in differences in the stock price index also from one period of another period and not only within the scope of one country but also in other countries (Sukirno, 2008)

Inflation will cause lack of incentives for investor to invest in securities, especially stocks. Investors will transfer their capital to short-term investments such as depositing in banks. This is what makes the difference in the magnitude of JII in 2015 compared to 2016 to 2019. This is possible because of a significant difference in inflation rates. An increase in inflation will cause an increase in production costs resulting in a decrease in the quantity of production and its profitability will also fall. (Mankiw et al., 2012) Thus it can be concluded that inflation has a negative influence on JII which means that if inflation rises it will cause the level of JII to fall and vice versa (Abidin, 2008). In Table 1.1 it can be seen that inflation has fluctuated. In 2016 inflation experienced a high decline of 3.53 and was accompanied by a large JII increase of 2,001,639 and then inflation declined again in 2017 to 2019 amounting to 3.81 and 3.01. This condition was accompanied by an increase in JII in the same year by 2,162,839 and 2,225,135. From these data, it is possible to have a negative relationship between inflation and JII

Another macro-variable which affects JII is interest rates. This is related when a company wants to produce, there must be capital. Triggering investors who do not have capital to borrow funds in banks. Interest rates at the banks themselves follow how much interest rates at BI (Tandellin: 2010). From this statement, it can be concluded that the high BI interest rates resulted in investors being reluctant to invest in the capital market, which resulted in decreased productivity, decreasing productivity resulting in lower profits, which made the stock prices go down and vice versa. In the sense that interest rates negatively affect the stock price index. If interest rates rise, the stock price index will go down and vice versa (Lubis, 2010).

In Table 1, it can be seen that interest rates have decreased in 2015 to 2017 with magnitudes of 7.52 and 4.56. This was accompanied by an increase in JII in the same year from $1,843,183$ to $2,162,460$. In addition to that, the interest rates will increase in 2018 by 5.1 . This was accompanied by a decline in JII in the same year for 2,126,460. From this data, it is possible that interest rates have a negative relationship with JII. This was accompanied by a decline in JII in the same year for 2,126,460. From this data, it is possible that interest rates have a negative relationship with JII. This was accompanied by a decline in JII in the same year for 2,126,460. From this data, it is possible that interest rates have a negative relationship with JII.

Exchange rate (ER) will also affect stock price index. Due to the increasing export capacity in Indonesia, the rupiah exchange rate has depreciated against the dollar. Depreciation is a decline in the value of a country's currency with a measure of the amount of currency of another country that can be bought. Meanwhile, appreciation is an increase in the value of a 
country's currency measured by the number of currencies of other countries that can be bought (Mankiw, 2006). It is well known that the exchange rate of the rupiah against the dollar has depreciated from 2015 to 2018 . With each the value is Rp. 13,457 per dollar and Rp. 14,267 per dollar. The statement can be seen in Table 1.1 along with the increase in JII in the same year with the value of 1,843,183 and 2,126,460. From these data it is possible that the exchange rate has a negative relationship with JII.

The increase in the exchange rate of the rupiah against the dollar has a negative impact on investors. This can be interpreted if there is an increase in the exchange rate of the rupiah against the dollar, meaning the economy has slowed so that the value of the dollar will result in a decrease in JII (Sunariyah, 2011). When investors continue to invest in the country while the state of the exchange rate weakens, this will add to the investment risk (Apriyansah, 2014) means the economy is slowing down so that the value of the dollar will cause a decrease in JII (Sunariyah, 2011).

The stock price increases when the money supply increases but the interest rate decreases, and vice versa (Samsul, 2006). It is known that the amount of outstanding money has increased from IDR 4,357,519.48 in 2015 to IDR 5,806,806.75 in 2018 (see Table 1.1). Along with that, there is an increase in JII in the same year with a value of 1,843,183 and 2,126,460. From these data, it is likely that the exchange rate has a positive relationship with JII.

\section{Literary Review and Hypothesis Development}

There are several studies that attempt to examine the effect of stock price indexes and macroeconomic variables both regionally and globally. Ibrahim and Yusoff (2001), Maghayereh (2003), Maysami et al. (2004), Menike (2006), Nugraha (2007), Yusof and Majid (2007), Majid and Yusof (2009), Asmy et al. (2010), Savasa and Samiloglub (2010), Syukma (2011), Albaity (2011), Beik and Wardhana (2011), Rad (2011), Kuwomu and Victor (2011), Hosseini et al. (2011), Istiqomah (2012), Hussin et al. (2012), Bekhet and Mugableh (2012), and Yahya et al. (2012) are several studies that examine the effect of stock price indexes and macroeconomic variables.

In these studies, the macroeconomic variable used was the Industrial Production Index (IPI) which proved to have a positive relationship with stock prices (Maysami et al. 2004). This is also in accordance with the research of Ibrahim and Yusoff (2001), Maghayereh (2003), Nugraha (2007) Avasa and Samiloglub (2010), Syukma (2011), Hosseini et al. (2011), Hussin et al. (2012), and Bekhet and Mugableh (2012). The increase in IPI will affect stock prices through its impact on company profits. The relationship between the Consumer Price Index (CPI) and stock prices can have a positive or negative effect. According to Maghayereh (2003), Syukma (2011), and Bekhet and Mugableh (2012) the two variables have a negative relationship. They stated that the rise in CPI indicated rising prices for consumer goods, which meant an increase in the cost of living. This makes people choose to allocate funds for consumption rather than investment. As a result, demand for shares in the capital market will decline. Low demand will make the share price go down. However, several other studies have shown that the two variables have a positive relationship. Ibrahim and Yusoff (2001), Maysami et al. (2004), Menike (2006), Asmy et al. (2010), Kuwomu and Victor (2011), Hosseini et al. (2011), Hussin et al. (2012) found that CPI was positively related to stock prices. demand for shares in the capital market will decline.

Low demand will make the share price go down. However, several other studies have shown that the two variables have a positive relationship. Ibrahim and Yusoff (2001), Maysami et al. (2004), Menike (2006), Asmy et al. (2010), Kuwomu and Victor (2011), Hosseini et al. (2011), Hussin et al. (2012) found that CPI was positively related to stock prices. demand for shares in the capital market will decline. Low demand will make the share price go down. However, several other studies have shown that the two variables have a positive relationship. Ibrahim and Yusoff (2001), Maysami et al. (2004), Menike (2006), Asmy et al. (2010), Kuwomu and Victor (2011), Hosseini et al. (2011), Hussin et al. (2012) found that CPI was positively related to stock prices.

Furthermore, the relationship between the money supply and the stock price can have a positive or negative effect. Maysami et al. (2004), Menike (2006), Majid and Yusof (2009), and 
Hosseini et al. (2011) show that an increase in the money supply will decline the interest rates. In this context, investors will invest their funds in the capital market. The increase in investment that occurs in the capital market will affect the demand for shares. The more requests, the higher prices will be. However. Ibrahim and Yusoff (2001), Asmy et al. (2010), Hussin et al. (2012), Bekhet and Mugableh (2012) show the opposite fact, where the relationship between the two variables turns out to be negative. The exchange rate and stock prices can also have a positive or negative effect. Studies conducted by Maysami et al. (2004), Nugraha (2007), and Asmy et al. (2010) show a positive relationship between the two variables. But according to Ibrahim and Yusoff (2001), Menike (2006), Yusof and Majid (2009), Syukma (2011), Kuwomu and Victor (2011), Hussin et al. (2012), and Bekhet and Mugableh (2012) the relationship between the two variables was negative.

This indicates that when the rupiah exchange rate depreciates, investors will divert their funds abroad so that capital outflows occur. The flow of funds abroad causes domestic investment to experience Bekhet and Mugableh (2012) the relationship between the two variables was negative. This indicates that when the rupiah exchange rate depreciates, investors will divert their funds abroad so that capital outflows occur. The flow of funds abroad causes domestic investment to experience a decrease.

This decrease has an impact on the reduced investment in shares in the domestic market so that share prices also decline. According to the research of Maghayereh (2003), Menike (2006), Kuwomu and Victor (2011), Hussin et al. (2012), interest rates have a negative effect on stock prices. This is due to the behavior of investors who tend to invest their funds in the form of investments other than shares, so the stock price goes down. Studies conducted by Yusof and Majid (2007) show that interest rate volatility affects the volatility of the conventional stock market but does not affect the Islamic stock market. This is in line with the sharia principle that interest rates are not a significant variable in explaining stock market volatility.

A study conducted by Triutami and Herlambang (2016) entitled "The Effect of Macro Variables on the Jakarta Islamic Index (JII)" examined the behavior of Jakarta Islamic Index (JII) as the dependent variable $(\mathrm{Y})$ through the influence of independent variables such as the exchange rate, inflation, and $\mathrm{BI}$ rate. By using multiple linear regression models, this research concludes that there is a relationship between the variables. First, the inflation rate partially has no significant effect on Jakarta Islamic Index (JII). Second, the interest rate partially has a significant negative effect on Jakarta Islamic Index (JII). Third, the exchange rate partially has a significant effect on Jakarta Islamic Index (JII). Fourth, inflation, interest rates, and exchange rates simultaneously have a significant effect on stock price movements on Jakarta Islamic Index (JII).

\section{Methods}

Analysis of the influence of national macroeconomic variables on the Jakarta Islamic Index (JII) is seen by using a number of variables, namely the Jakarta Islamic Index (JII), the money supply (M2), the exchange rate (ER), the interest rate of Bank Indonesia (BI Rate), inflation (INF). The form of the long-term regression results are as follows;

$$
J I I=\partial+\beta_{1} I N F_{i t}+\beta_{2} E R_{i t}+\beta_{3} B I R A T E+\beta_{4} M 2_{i t}+R E S I D_{i t}
$$

Where JII is Jakarta Islamic Index, INF is inflation, ER is Exchange Rate, BIRATE is Interest Rate, and M2 is Money Supply.

ECM is one of the models used to correct equations of regression between individual variables that are not stationary so that they return to equilibrium in the long run, with the proviso that these variables must be co-integrated between variables (Ajija, et al. 2011). In this case, the ECM serves to correct short-term relationships towards the long-term balance introduced by Sargan and popularized by Engel and granger. After all the variables pass the co-integration test, it is processed to ECM test. The ECM model is formed from the residual long-term equation. The long-term residual is used for error correction error correction (ECT). Which influences the short- 
term equation. The following is the form of the ECM model equation in this study:

$$
D J I I=\partial+\beta_{1} D I N F_{i t}+\beta_{2} D E R_{i t}+\beta_{3} D B I R A T E+\beta_{4} D M 2_{i t}+R E S I D_{i t}
$$

Where, JII is Jakarta Islamic Index, INF is inflation, ER is Exchange Rate, Birate is Interest Rate, M2 is Money Supply and RESID01t-1 is residual Equation or called Error Correction Term (ECT).

The ECM model can be valid if the cointegrated variables are supported by significant and negative ECT coefficient values. If the ECT coefficient has a positive effect, the direction of the variables used will be further away from the long-term equilibrium so that the ECM model cannot be used (Rahutami, 2011). The variable used in the study is Jakarta Islamic Index (JII) which is a Sharia-based stock index in Indonesia. The money supply (M2) is the money supply in a broad sense, Exchange Rate (ER) is the exchange rate of the rupiah against the US dollar (Rp / USD), BI Rate represents the interest rate of Bank Indonesia and Inflation (INF) is the inflation rate in Indonesia

The type of data used in this research is secondary data in the form of time series and in the form of monthly data in 2015-2019. With the object of research in the Indonesian Islamic capital market. There are economic and methodological reasons in research in the use of monthly data from 2015-2019. First, the selection of a fairly long time span of 5 years with the type of time series data is good enough for testing. Second, there are limitations of Index data especially in the Jakarta Islamic Index (JII). In 2014, there was no data, thus the data is taken from 20152019. This time span of 5 is very interesting to do the test because there is a gradual increase in economic growth for it is in tandem with the size of exports in Indonesia. Therefore, it can show how stock movements and macro variables respond to this. In addition, with a fairly long period of time, it is expected to minimize the estimation errors. This data source was taken from the Financial Services Authority and Bank Indonesia.

The analytical method used in the study uses two analytical methods, namely descriptive statistics and quantitative analysis. Descriptive statistics on this model aims to explain or describe the object of research by looking at the effect of macro variables and international sharia stock indexes on the Jakarta Islamic Index (JII). After that to strengthen the results of the descriptive statistical test continued by using quantitative data analysis using the Error Correction Mechanism (ECM) model. By using time series data, before estimating, you must test the data using data stationarity test. This test aims to avoid the occurrence of spurious regression.

One way to identify the relationship between variables that are stationary is to do modeling corrections for errors. But if there is co-integration non-stationary data, then the error test is declared valid. This requirement is explained by Engle-Granger's theory (Ariefianto, 2012). Error Correction Model (ECM) is one of the estimation models used to test the regression equation among individual variables that are not stationary in order to return to equilibrium in the long run (Ajija, et al, 2011).

\section{Classic Assumption Test}

The multiple regression or multiple regression model is a model that consists of independent variables regressed. This classic assumption test is conducted to find out whether there is a problem in the regression model or not to fulfill the Best Linear Unlock Estimator (BLUE) rules. As for other conditions that must be fulfilled, it can be used that can be free from assumptions, namely non-multicollenearity, homoscedasticity, and non-autocorrelation (Ajija, et al. 2011).

Multicollinearity means that there is a perfect linear relationship or starch between some or all variables that explain the regression variable. The presence or absence of multicollinearity can be seen from the correlation coefficient of each independent variable. If the correlation coefficient is greater than 0.8 , then multicollinearity occurs. Therefore, heterokedasticity is a state of all the disorders that arise in the population regression function which does not have the same variant. The heteroscedasticity test can be curved with the following steps (Ajija, et al. 2011): 
Conduct residual patterns from the results of regression estimates. If the residual moves constant, then there is no heterokedasticity. On the other hand, if the residue forms a certain pattern, it is heteroscedastic and to prove the suspicion with the first heterokedasticity test. A White Heterocedasticity test is available in Eviews. Then notice the value of Obs * R-Squared. If the value is smaller than X2 tables, then heterocedastic does not occur. And vice versa (Ajija, et al. 2011). Then, Linearity test is a test conducted to see whether the specifications of the model used are correct or not. To find out the data is linear or can not be known by doing the Ramsey test (RESET), which is a test developed by Ramsey by developing a general test of specification errors or known as regression specification error test (Regression specification error test (RESET)) (Widarjono, 2013).

\section{Stationarity Test}

In carrying out tests on time series data it is necessary to have a stationarity test. This stationary data test is useful for obtaining stable mean values and random errors equal to zero, so that this regression model has good predictive ability in avoiding spurious regression data. Faulty regression is a regression of the results of these data shows a high determination (R2) but the actual relationship between variables has no meaning (Gujarati, 2004). The following below are ways to test stationarity which are Unit Root Test and Integration Test. First, the unit root test is a formal test conducted by David Dickey and Wayne Fuller. This root test is done to find out whether the data used for research is stationary or not. Stationary data is data that does not contain roots or units and vice versa. Data testing was performed using the Augmented Dickey Fuller (DF) test. Second, Integration Test is a test of the degree of integration using the unit root test at the level of level shows that the data is not stationary, then the stationarity test can be continued at different levels.

\section{Cointegration Test}

Cointegration test is a test that is useful for detecting long-term relationship stability between two or more variables. If among the variables studied there is cointegration, then these variables have a long-term relationship. Data time series there is cointegration in the variables if the residual is from a stationary regression level, then the regression will show the right estimate in the longterm relationship. Cointegration testing can be done with the Johansen test and the EngelGranger test. The Engel-Granger test is a test that utilizes the Augmented Dickey-Fuller test by estimating the regression model, followed by calculating the stationary residual value. The regression is called a cointegration regression (Ariefianto, 2012).

\section{Results and Discussion}

Data stationarity test is an important step in analyzing time series data. Unit root test results at the level can be seen in Table 2 .

Table 2. Unit root test: level

\begin{tabular}{ccccc}
\hline Series & Prob. & Lag & Max Lag & Obs \\
\hline JUB & 0.9576 & 6 & 10 & 49 \\
BEER & 0.5015 & 1 & 10 & 54 \\
ER & 0.1391 & 0 & 10 & 55 \\
INF & 0.2399 & 0 & 10 & 55 \\
JII & 0.4051 & 0 & 10 & 55 \\
\hline
\end{tabular}

The stationarity test results at the level indicate that all variables are not stationary. This is because the probability value is greater than the alpha value of $5 \%$. Research with non-stationary data can produce spurious regression. Therefore, the stationarity test is continued at the first difference level. 
Table 3. Unit root test: first different

\begin{tabular}{ccccc}
\hline Series & Prob. & Lag & Max Lag & Obs \\
\hline D (JUB) & 0.0355 & 5 & 10 & 49 \\
D (BEER) & 0.0001 & 0 & 10 & 54 \\
D (ER) & 0.0000 & 0 & 10 & 54 \\
D (INF) & 0.0000 & 1 & 10 & 53 \\
D (JII) & 0.0000 & 0 & 10 & 54 \\
\hline
\end{tabular}

The data stationarity test results in the table show that all data used in the study are stationary at the first difference level. This is because the probability value is smaller than the alpha of $5 \%$.

Table 4. Cointegration test

\begin{tabular}{lccc}
\hline & t-Statistics & Prob. ${ }^{*}$ \\
\hline Augmented Dickey-Fuller test statistic & -4.474319 & 0,0007 \\
\hline Test critical values: & $1 \%$ level & -3.555023 & \\
& $5 \%$ level & -2.915522 & \\
& $10 \%$ level & -2.595565 & \\
\hline
\end{tabular}

The results of the co-integration test in the table are derived from the residuals that are stationary tested at the first different level which indicates that the data used is cointegrated. This is because the probability value is below the alpha of $5 \%$. Hence, the data can proceed to the next stage.

Table 5. Effect in the short term

\begin{tabular}{lrrrr}
\hline \multicolumn{1}{c}{ Variable } & Coefficient & Std. Error & t-Statistics & Prob. \\
\hline C & 11178.50 & 12128.47 & 0.921674 & 0.3612 \\
D (ER) & -74333.39 & 37042.93 & -2.006682 & 0.0503 \\
D (INF) & 375.5478 & 24248.12 & 0.015488 & 0.9877 \\
D (JUB) & -0.121522 & 0.208266 & -0.583493 & 0.5622 \\
D (BEER) & 21574.24 & 44868.07 & 0.480837 & 0.6328 \\
ECT (-1) & -0.508848 & 0.112749 & -4.513090 & 0.0000 \\
\hline R-squared & 0.331893 & Mean dependent var & 3405,001 \\
Adjusted R-squared & 0.263718 & SD dependent var & 86635.36 \\
SE of regression & 74339.08 & Akaike info criterion & 25.37333 \\
Sum squared resid & $2.71 E+11$ & Schwarz criterion & 25,59231 \\
Log likelihood & -691.7666 & Hannan-Quinn criter. & 25.45801 \\
F-statistics & 4,868299 & Durbin-Watson stat & 1.668459 \\
Prob (F-statistic) & 0.001079 & & & \\
\hline
\end{tabular}

Table 6. Effect in the long term

\begin{tabular}{crrrr}
\hline Variable & Coefficient & Std. Error & t-Statistics & Prob. \\
\hline C & 3296724 & 371636.2 & 8.870836 & 0.0000 \\
BEER & -12828.26 & 18756.27 & -0.683945 & 0.4971 \\
ER & -220172.1 & 38236.67 & -5.758141 & 0.0000 \\
INF & 1805,540 & 16029.16 & 0.112641 & 0.9108 \\
JUB & 0.364719 & 0.050357 & 7.242632 & 0.0000 \\
\hline R-squared & 0.745119 & Mean dependent var & 2060903. \\
Adjusted R-squared & 0.725128 & SD dependent var & 181466.2 \\
SE of regression & 95139.53 & Akaike info criterion & 25,84912 \\
Sum squared resid & $4.62 \mathrm{E}+11$ & Schwarz criterion & 26.02996 \\
Log likelihood & -718.7754 & Hannan-Quinn criter. & 25,91923 \\
F-statistics & 37,27330 & Durbin-Watson stat & 1.106380 \\
Prob (F-statistic) & 0.000000 & & \\
\hline
\end{tabular}




\section{Effect of Macro Variables on JII in the Long Term}

Cointegration test results show that in 2015-2019 there was a long-term relationship between inflation variables, BI interest rates, money supply and foreign exchange rates with JII. From the results of the long-term regression test it can be seen that the probability value is 0.000000 smaller than alpha 0.05 (Table 6), so it can be concluded that in the long run all variables together influence JII. The exchange rate has a coefficient of -220172.1 it can be concluded that in the long run the exchange rate has a negative effect on JII. This result is consistent with the research of Maghayereh (2003) also states that the exchange rate has a negative effect on stock returns. But different from the results of the study of Islam et al.

The money supply has a coefficient of 0.364719 so it can be concluded that in the long run the exchange rate has a positive effect on JII. These results are in accordance with the research of Maysami et al. (2004), Menike (2006), Majid and Yusof (2009), and Hosseini et al. (2011) which show that an increase in the money supply has a positive effect on stock prices. However, in contrast to the research of Ibrahim and Yusoff (2001), Asmy et al. (2010), Hussin et al. (2012), Bekhet and Mugableh (2012), they show the opposite fact where the relationship between the two variables turns out to be negative.

\section{Effect of Macro Variables on JII in the Short Term}

ECM test results show that in 2015-2019 there was a short-term relationship between inflation variables, BI interest rates, money supply and foreign exchange rates with JII. This is consistent with research by Lestari (2005), Purwanto (2007), and Prasetiono (2010), that BI interest rate inflation, money supply and exchange rates affect stock prices in the short term. This can be understood because there is a spontaneous (short-term) investor reaction to changes in SBI interest rates, inflation and the exchange rate for the purchase of shares, including shares included in the Jakarta Islamic Index criteria.

The results of the discussion indicate that there is a significant effect both long and short term between macro variables, inflation, BI interest rates, the money supply, and inflation with JII. This shows that macro variables play an important role in determining JII, so for companies to be more analyzing macro variables in running their companies, because macro variables can affect the company's performance which will ultimately affect the movement of sharia stock prices. the government also has an important role in this regard, because macro variables are related to policies in the capital market sector. This means that the government is obliged to be able to control macro variables so that it can support an economic improvement which will ultimately affect the financial performance of companies included in JII.

\section{Conclusion}

This study aims to determine and explain how the influence of macro variables, namely: inflation, SBI interest rates, foreign exchange rates, and the money supply to the 2015-2019 Jakarta Islamic Index in the long term and short term. Based on the analysis that has been done through cointegration and ECM tests, there is a long-term relationship between inflation variables, BI interest rates, foreign exchange rates, and the money supply with JII in 2015-2019. There is a short-term relationship between inflation variables, SBI interest rates, foreign exchange rates, and the money supply with JII during 2015-2019.

Investors in investing can consider economic conditions such as inflation, SBI interest rates and foreign exchange rates because based on the results of this study inflation, SBI interest rates, and long-term and short-term foreign exchange rates affect the stock price index. The next researcher is expected to be able to use different samples and use or add different macroeconomic variables that are thought to affect the stock price index in the long term and short term, such as national income, economic growth, oil prices and so on. 


\section{Reference}

Abidin, Z. (2008). Analysis of the Relationship Between Sharia Stock Indices in Several Countries and Jakarta Islamic Index (III) Stock Indices in Indonesia. Bogor: Bogor Agricultural University.

Albaity, MS. (2011). Impact of the Monetary Policy Instruments on Islamic Stock Market Index Return. Discussion Paper, 26

Apriyansah, Y., \& Prabawa, S. A. (2014). Analysis of the Effects of Exchange Rates, Bank Indonesia Certificate Interest Rates, Inflation, and the Nikkei 225 Index on the Composite Stock. Index on the Indonesia Stock Exchange. Bengkulu. Bengkulu University

Ariefianto, M. D. (2012). Ekonometrika esensi dan aplikasi dengan menggunakan EViews. Jakarta: Erlangga.

Asmy, M., Rohilina, W., Hassama, A. \& Fouad, Md. (2010). Effects of Macroeconomic Variables on Stock Prices in Malaysia: An Approach of Error Correction Model. MPRA Paper. 20970.

Ajija, S. R, Wulandari, D., Setianto, R.H., \& Primanthi. M.R. (2011). Smart Ways to Master Eviews. Jakarta: Salemba Empat

Beik, I.S \& Wardhana. W (2011). The Relationship between Jakarta Islamic Index and Other Selected Markets: Evidence from Impulse Response Function. Economic Magazine, 21(2).

Bekhet, HA \& Mugableh. M.I (2012). Investigating Equilibrium Relationship between Macroeconomic Variables and Malaysian Stock Market Index through Bounds Tests Approach. International Journal of Economics and Finance, 4(10).

Gujarati, D (2004), Basic Econometrics. Jakarta: Salemba Empat

Hosseini, S. M, Ahmad, Z \& Lai, Y. W. (2011). The Role of Macroeconomic Variables on Stock Market Index in China and India. International Journal of Economics and Finance, 3(6).

Ibrahim, M.H., \& Yusoff, W.S.W. (2001). Macroeconomic Variables, Exchange Rate and Stock Price: A Malaysian Perspective. Journal of Economics and Management, 9(2), 141-164.

Istiqomah. (2012). The Dynamics of Interaction Between Monetary Variables and Islamic Capital Market on Indonesian Economic Growth [thesis]. Bogor: Bogor Agricultural University.

Kuwomu, J.K M., \& Victor, O. N., (2011). Macroeconomic Variables and Stock Market Returns: Full Information Maximum Likelihood Estimation. Journal of Finance and Accounting. 2 No.4.

Lubis, I. F. (2010). Effect of Interest Rates and Exchange Rates on Banking Stock Prices on the Indonesia Stock Exchange. Master of Management, Open University, Jakarta.

Maghayereh, A. (2003). Causal relations between Stock Prices and Macroeconomic Variables in the Small, Open Economy of Jordan. REACH: Econ \& Adm, 7 (2): 3-12.

Majid, M. S. A., \& Yusof, R.M. (2009). Long-run relationship between Islamic stock returns and macroeconomic variables An application of the autoregressive distributed lag model. Humanomics Journal. 25(2), 127-141.

Mankiw, N. G., Quah, E., \& Wilson, P. (2012). Introduction to the Asian Edition of Macro Economics. Jakarta: Selemba Empat

Mankiw, N G. (2006). Macroeconomics. Jakarta: Erlangga.

Maysami, R. C, Howe., L.C \& Hamzah, M.A (2004). Relationship between Macroeconomic Variables and Stock Market Indices: Cointegration Evidence from Stock Exchange of Singapore's All-S Sector Indices. Management Journal. 24, 47-77. 
Menike, L. M. C. S. (2006). The Effect of Macroeconomic Variables on Stock Prices in Emerging Sri Lankan Stock Market. Sabaragamuwa University Journal. 6(1), 50-67.

Nugraha, G. P. (2007). Analysis of the Effect of Capital Market Developments on Indonesia's Economic Growth [thesis]. Bogor: Bogor Agricultural University.

Rad, A. A. (2011). Macroeonomic Variables and Stock Market: Evidence from Iran. International Journal of Economics and Finance Studies. 3 (1)

Savasa, B \& Samiloglub, F. (2010). The Impact Of Macroeconomic Variables On Stock Returns in Turkey: An ARDL Bounds Testing Approach. Afyon Kocatepe Universitesi. II.

Soemitra, A. (2009). Sharia Banks and Financial Institutions. Jakarta: Kencana

Sukirno, S. (2008). Macroeconomics Introduction Theory. Third Edition. Jakarta: PT Raja Grafindo Persada.

Sunariyah. (2011). Introduction to Capital Market Knowledge. Sixth Edition. Yogyakarta: UPP STIM YKPN.

Syukma, N. H. (2011). Macroeconomic Factors Affecting Coal Stock Return in the Jakarta Islamic Index Group [thesis]. Bogor: Bogor Agricultural University.

Tandellin, E. (2010). Portfolio and Investment Theories and Applications: First Edition. Yogyakarta: Canisius.

Widarjono, A. (2013), Econometrics: Introduction and Application with Eviews Guidelines. UPP STIM YKPN, Yogyakarta.

Yahya. M., Muhammad, F \& Awang, S.A. (2012). Macroeconomic Variable and Malaysian Islamic Stock Market: A time Series Analysis. Journal of Business Studies Quarterly, 3(4),1-13.

Yusoff, R. M \& Majid, M. S. A. (2007). Stock Market Volatility Transmission in Malaysia: Islamic Versus Conventional Stock Market. Journal of Islamic Economics. 20(2), 17-35. 